\title{
TEACHER CERTIFICATION: A WAY TO LEAD TEACHER FOR PROFESSIONAL DEVELOPMENT AND LIFELONG LEARNING
}

\author{
Kuzairi $^{1}$ \\ 1. Program Studi Pendidikan Bahasa Inggris STKIP PGRI Banjarmasin \\ spirit.ahmadkzr@gmail.com ( 087850673437$)$
}

\begin{abstract}
Indonesian Government launched teacher certification program in order to increase the quality of teachers. This policy is expected to foster teacher's competences and prosperity. In terms of competency, this program enhances teachers to develop their professionalism especially in teaching and other academic activities. Test and training are provided to take this program. Several requirements such as the minimum qualification, teacher's portfolio are also given as the elements or components of the teacher certification program administration. Dealing with the prosperity, teachers who passed this program are also given financial support. Some studies on the effectiveness of teacher certification program were conducted. The results showed that this program does not guarantee teachers to have quality improvement. However, it does not mean this program is not successful at all or it does not have any advantage or contribution for teachers. Therefore, this paper aims to discuss on how far teacher certification program lead teachers to develop their professionalism and bring them into lifelong learning activities or situation.
\end{abstract}

Kata Kunci: Teacher Certification, Teacher Professional Development

\section{INTRODUCTION}

Education is one of the fundamental priorities of nation building. Qualified Education will lead the nation to achieve growth and development well. For this reason, the Indonesian government continuously seeks to improve the quality of its education. Improving the quality of education can be done by using many strategies, such as reforming school curriculum, school systems, empowering teacher's quality, providing enough and good infrastructures, etc.

Teacher, as one of the important components of education, has a vital position to develop the education. Teacher is one of the main pillars in educational system. $\mathrm{He}$ or she is the key of quality educational improvement and becomes role model for the studets. Students look up to him for knowledge, wisdom, manners, morals inspiration, enlightenment, and so on. Therefore, the competency of teachers should be improved and broaden to be in line with the fast development of knowledge and technology.

Indonesian Government has launched some programs regarding the teachers improvement such as providing scholarships, giving training, seminar and workshop. Nowadays, the Government of Indonesia has paid more attention to the quality of teachers. For the sake of incresing the quality of education in this country. The 
government obligates teacher to take Teacher Certification as the basic requirement for a professional.

The teacher certification program had been launched in 2005. The objective of this program does not only improve teachers' prosperity through their professional incentive, but also improve teachers' competencies and professionalism. The result expected from this certification is the improvement of quality learning performed by teacher in the classroom. In other words, teacher certification is viewed as one of the affective way to promote teacher and school for better quality of education as well as it also helps teachers to increase the prosperity of the teacher in terms of financial support.

Nowadays, many teachers have been certified, either by portfolio assessment or by attending teacher training. By passing this program, it is believed that they have good capabilities in teaching their students. It is proved by the documents they submit and teaching assessment by the evaluator. Certified teachers are believed to perform better than teachers who have not been certified. People assume that they have enough competencies in teaching.

However, there are many issues relating to the teacher certification. Although the teachers have done or passed the program, teachers perform their best only during the program but not after it. Teachers have high motivation to arrange lesson plans and attend any seminars related to their major. The problem is that they do these activities not because they want to enhance their quality of teaching but because they want to pass the certification program and get the profession financial support. There have been many rumors saying that certified teachers do not always lead to professionalism. These rumors may come arise because the phenomenon showing that teachers do not make lesson plan, use various method in teaching, use of media, or arrange a good evaluation mechanism. This skepticism appears from different people related to the teacher certification program.

Some studies have been conducted relating to how effective the teacher certification in increasing the teacher quality. Triyanto (2012) stated on his research that "the certified teachers do not show significant performance improvement, though they have received an additional allowance as much as their basic salary." This research shows that the teacher certification through portofolio assessment is rather uneffective because of some factors, one of them is many documents were not rational. For example, there was a participant hold three certificates of seminar at the same time. There were several frauds done by teacher to get a certificate. Besides, there was also allegations of bribery and falsification of documents. So according to this study, it can be concluded that the certifiation program through portofolio assessment has not succeded in improving the teacher quality in indonesia. Therefore, the government changes the portfolio assessment method with the education and training for teachers.

Halim (2011) mentioned in his research that "in the certification, assessors only assess teachers" portfolios. In other words, this certification does not help teachers to develop their competences." In this case, the professional competences relate to communicative competence which consists of grammatical competence, sociolinguistic competence, discourse competence, and strategic competence. He also 
suggested that a training program to increase teachers' communicative competence should be given before being certified.

Setiawan (2009) mentioned in his study about teacher certification in Indonesia is less effective. This is because the programs do dot follow by monitoring after the teacher has already been certified. Besides, most of the teachers only focus on the quantity which relate to how many seminars they attend, how many training they have done. So, They leave the classroom activities to attend the seminar, workshop, training programs because it will be counted for the teachers certification process, and not necessarily the quality of the programs, not to mention the impact of the programs for the students in the classroom setting which actually become the most responsibility for them.

A research has been conducted in certain area such as in South Sumatra Province which was done by Khodijah (2010). This study stated that the teachers' performance after passed the program, either as a whole, and viewed from the aspect of lesson planning, implementation of learning, learning assessment, and professional development, all indicate that the performance is still below standard. Besides, this research showed that there is no between teachers who live in urban and in rural areas, and between those who pass the certification program through portfolio and PLPG.

A reseach which showed an effective result of the teacher certification program toward the learning and teaching quality conducted in Semarang Regency by Winarsih (2008). This study investigated the implementation of Primary School Teacher Certification Policy in Semarang district. The research result showed that the implementation of teacher certification for basic education in Semarang district tends to be good in general. In communication factor, transmition and consistency subfactor are supporting the implementation well but clarity subfactor is not good enough.

Altohough some research in some certain areas of Indonesia found that the teacher certification program has given cotribution for the teacher in improving the learning and teaching quality, it is still needed to maximaze the effectiveness of this program. Since the main purpose of teacher certification program is to enhance the professionalism of teachers, certified teachers should be teachers who are professional.

The validity of teacher certification program is being questioned. It doesn't guarantee whether teachers who have passed the teacher certification program are really professional teachers, teachers who are eligible to teach. Many assumptions state that teacher certification program is only a waste of time and money since teachers are only interested in the high salary without any quality improvement.

\section{DISCUSSION}

\section{A. Teacher Cert ification \\ 1. Definition}

Based on the Law number 14/ 2005 about teacher and lecturer section 1 (1), teacher certification is defined as a process of giving an educator certificates to teachers and lecturers. In relation to this definition, Samani et al (2006: 1) say that teacher certification is a process of giving an educator certificate to teachers 
who have fulfilled the requirements. It means that the certificates will be given to teachers and lecturers after they have fulfilled the requirements which have been set by the government.

\section{Goals}

The main objectives of the certification process in Indonesia are: (1) identifying suitable teachers to fulfil the aims of national education (2) improving the process of practice teaching and the quality of the graduating teachers and (3) improving teachers professionalism (Samani, et ALL, 2006). Beside these objectives, there are benefits made by the government. Those benefits include increased wages for teachers thus, preventing them from seeking additional employment to supplement their income.

\section{Mechanism}

Teacher certification is the mandate of the act of the Republic of Indonesia Number 20, Year 2003 On National Education System. Teacher certification can be done in two ways, they are: (1) Teachers ${ }^{\text {ee }}$ portfolio assessment, and (2) certification which is directly given to the teachers. In order to get teacher certificate, teachers can do competency test. This test can be in the form of portfolio assessment which is the acknowledgement of teacheres professional experience by assessing towards documents which reflects the teacher"s competencies.

Teachers who follow the teacher certification program by submitting portfolio should fulfill some requirements. They are: (1) having S-1 academic qualification or D-4 from study programs which have study license, (2) have been teaching for at least four years (in governmental or nongovernmental institution) and when The Act of the Republic of Indonesia Number 14, year 2005 On Teacher and Lecturer is legalized, they have been teachers, (3) teachers and assessors who have not had the S-1/ D-4 academic qualification who have reached 50 years old of age and owned IV/a faction.

While teachers who can follow the second mechanism of teacher certification, that is by directly get the certificate, are teachers who can fulfill all the requirements that the government has set. The requirements are: (1) teachers or assessors who have S-2/S-3 academic qualification from accredited universities in teaching or other studies which are relevant with their teaching subject, or class teachers with IV/b faction; (2) teachers or assessors with IV/c at minimum. For teachers whose competency test is in the form of portfolio assessment, they have to submit their portfolio which covers: (1) academic qualification, (2) teacher training and education, (3) teaching experience, (4) lesson plan, (5) evaluation from the headmaster and assessor, (6) academic achievement, (7) profession development project, (8) participation in seminar or workshop, (9) organization experience in social and education field, and (10) certificates/ honor which are relevant with education. If the portfolio assessment has not reached the minimum passing grade, the LPTK or Lembaga Pendidikan dan Tenaga Kependidikan will set some alternatives as follows: 1). Doing activities related to the teacher profession in order to complete the portfolio. 2). If in one month the teacher cannot complete the portfolio, he has to follow the PLPG or Pendidikan dan 
Latihan Profesi Guru which involves four teacher competencies and ends with a competency test.

Another way which can be done in conducting teacher certification is by directly giving the certificate to the teachers who fulfill the requirements. The requirements can be explained as follows.

1) Teachers with graduate and post-graduate qualification should submit: copies of S-1 diploma, S-2/SS-3 diploma and academic transcript, copies of rank/ the last faction decree, study license, teaching decree, and recommendation from the local education department.

2) Teachers with IV.c faction should submit: copies of S-1 diploma,S-2/ S-3 diploma, academic transcript, rank/ the last faction decree, and recommendation from the local education department.

\section{B. Teacher Professional Development and Lifelong Learning}

Teacher plays important role in achieving the qualified outcomes in education. A teacher performs many functions in the classroom for the comprehensive development of the students. Teacher keeps the students safe, decides what is important for the students to learn, presents a rich and organized body of information to students, protects and improves the students' self-esteem, provides an environment for the students to explore a variety of experiences, helps students to use technology-related tools to accomplish certain tasks, makes sure that the students are prepared for the next level of education, loves and nurtures the students.

A teacher, as a professional educator, should fulfill 3 requirements: (1) having academic qualification, (2) having competency, (3) having teacher certificate (Diknas, 2006: 4). The competency of teacher can be classified into four areas of competency, they are pedagogical, personal, professional, and social competency. In brief, each competency encompasses the following: (1) the pedagogical competency is a teacher's ability to manage students' learning which includes lesson plan, learning evaluation, and students' potency actualization (2) the personal competency includes demonstrating certain characteristics, such as faith and devoutness, stability, maturity, sensibility, etc. Teacher should be critical and skeptical in doing his duty to deliver his lesson (3) the social competency is teachers' ability to be part of the community such as communicating and socializing effectively with students, fellow teachers, teaching staff, and students' parents. (4) The professional competency is teachers' ability to master science, engineering, and/or art (in other words, content or subject knowledge).

The law of Ministry of National Education of Republic of Indonesia number 16, 2007 about academic qualification standard and teachers' competences derives the four competences for the subject matter teachers for elementary and secondary schools as follows: 
Table 1

Teachers' Main Competences

Teachers' Main Competences

\section{Pedagogic Competence}

1. Mastering the students' characteristics from the physical, moral, spiritual, social, cultural, emotional, and intellectual aspects

2. Mastering the educative learning theories and principles

3. Developing the curriculum related to the subject matter

4. Conducting educative teaching and learning

5. Utilizing the technology, information and communication for teaching and learning concern

6. Facilitating the students' potential development to actualize their potentials

7. Communicating with the students effectively, emphatically, and politely.

8. Conducting assessment and evaluation of the learning process and results

9. Utilizing the results of assessment and evaluation for teaching and learning concern

10. Doing reflective action for teaching and learning quality improvement

\section{Personal Competence}

11. Having appropriate behavior with the religious, law, social, and cultural norms of Indonesia

12. Being an honest person, having good attitude, and being a good model for students and societies

13. Being a stable, mature, wise and authoritative person.

14. Showing high working ethos, responsibilities, pride of being teacher and self confidence.

15. Holding with high esteem the code ethics of teachers

\section{Social Competence}

16. Having exclusive attitude, objective and indiscriminative behaviors

17. Communicating with colleagues, educational administrators, parents, and societies effectively, emphatically, and politely

18. Adapting in every area of Indonesia where the duty takes place

19. Communicating with the same and different professions community in spoken or written

\section{Professional Competence}

20. Mastering the materials, structures, concepts, and scientific way of thinking to support the subject matter possessed

21. Mastering the standard competences and basic competences of the subject matter

22. Developing teaching and learning materials of the subject matter creatively

23. Developing the profession continuously through reflective action

24. Utilizing technology, information and communication for self development.

(Source: Permendiknas, No. 16 Tahun 2007)

A competency test is needed by teachers to obtain the teacher certificate which is now done through portfolio assessment. The teacher's portfolio used for certification contains a collection of documents of the teacher's activities since becoming a teacher up to the present, reflecting professional performance. The 
document consists of among other things formal education background, professional trainings, teaching experience, sample of lesson plans, evaluation made by the headmaster and supervisor, academic achievement, academic papers, attendance in academic forum, experience in professional organizations, and awards that have been given to the teacher. The teacher's portfolio is then evaluated by a special committee from a number of universities. The teacher certificate is provided for teachers who have already passed the evaluation process. Teachers whose scores on their portfolio are less than the minimum score can add new entries in their portfolio or attend a special training.

In addition, Brown (2007:491) lists four major characteristics of good language teachers. Those are technical knowledge, pedagogical skills, interpersonal skills, and personal qualities. The characteristics are completely listed in the table below:

Table 2

Characteristics of Good Language Teachers Characteristics of Good Language Teacher

\section{Technical Knowledge}

1. Understands the linguistic system of English Literature and discourse

2. Comprehensively grasps basic principles of language learning and teaching

3. Has fluent competence in speaking, writing, listening and reading English

4. Knows through experience what it is like to learn a foreign language

5. Understands the close connection between language and culture

6. Keeps up with the field through regular reading and conference/workshop attendance.

\section{Pedagogical Skills}

7. Has a well-thought-out, informed approach to language teaching

8. Efficiently designs and executes lesson plans

9. Understands and appropriately uses a variety of technique.

10. Monitors lessons as they unfold and makes effective mid-lesson alterations

11. Effectively perceives students' linguistic and personal needs, along with their various styles, preferences, strengths and weaknesses

12. Gives optimal feedback to students

13. Stimulates interaction, cooperation and teamwork in the classroom

14. Uses appropriate principles of classroom management

15. Uses effective, clear presentation skills

16. Creatively adapts textbook material and other audio, visual, and mechanical aids

17. Innovatively creates brand-new materials when needed

18. Uses interactive, intrinsically motivating techniques to create effective tests.

\section{Interpersonal Skills}

19. Is aware of cross-cultural differences and is sensitive to students' cultural traditions

20. Enjoys people; shows enthusiasm, warmth, rapport and appropriate humor

21. Values the opinions and abilities of students 
22. Is patient in working with students with lesser ability

23. Offers challenges to students of exceptionally high ability

24. Corporates harmoniously and candidly with colleagues, including seeking opportunities to share thoughts, ideas and techniques

\section{Personal Qualities}

25. Is well organized, conscientious in meeting commitment, and dependable

26. Is flexible when things go awry

27. Engages in regular reflection on one's own teaching practice and strives to learn from those reflective practices

28. Maintains an inquisitive mind in trying out new ways of teaching

29. Sets short-term and long-term goal for continued professional growth 30. Maintains and exemplifies high ethical and moral standards.

(Source: Brown, 2007:491)

\section{Leading Teacher Professional Development and Lifelong Learning through Teacher Certification}

Professional teacher is a lifelong learner. Several stages on how teacher professional development and lifelong learning are carried out were constructed. Those stages deal with skill learning, cognitive process, personal construction, and reflective practice. Skill learning requires teachers to develop a range of the basic skills such as designing lessons, managing classrooms, assessing performance, etc. cognitive process relates to teachers' background, experience, knowledge, and beliefs which all contribute to an underlying set of cognitive assumptions about teaching and learning. The next stage is personal construction in which teachers' knowledge is actively constructed and not passively received in an ongoing process of reorganization and reconstruction as new learning and experiences form a personal framework. The last stage is reflective practice. At this stage, teacher can benefit greatly from focused reflection and critical examination of their own teaching experiences. This situation then leads them to the improvement and further development (Brown, 2007:486-487).

Teacher certification program is designed to lead teachers into professional development and quality improvement as well as enhance them to be a lifelong learning context. It can be interpreted that how teacher certification program can help teachers in fostering their skills and expertise into an ongoing development and willingness to be lifelong learners. It means that by taking this certification program, teachers are expected to have self-improvement and development in terms of their profession as a teacher. This improvement should also lead teachers into creativity and innovation stages in which they need to learn lifelong. These three stages which are teacher certification (TC), professional development (PD), and lifelong learning (LL) can be drawn as following figure. 


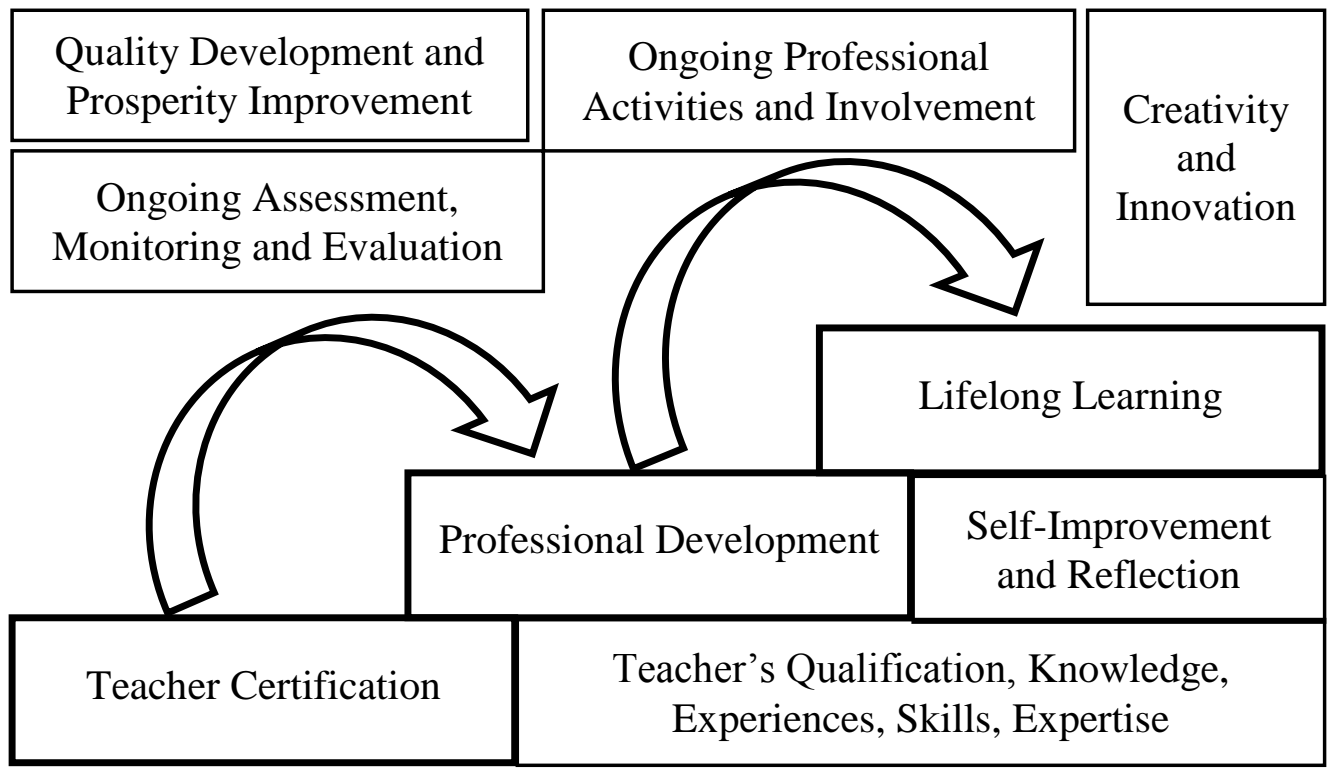

Figure 1. Leading teacher professional development and lifelong learning through Teacher Certification program

The starting point of the three stages is teacher certification. At this stage, teachers are administered about their qualification, knowledge, experiences, skills and expertise. This program investigate how far the teacher competences and qualification through PLPG and portfolio documents. Those who have passed this program should not be let them go by any further activities or obligation. They need to be given ongoing assessment, monitoring and evaluation on how the teacher certification program affect or influence their professionalism. Therefore, teachers are required to do self-improvement and reflection by getting involved in various professional activities. These self-improvement and reflection are expected to build teachers' creativity and innovation. These all ongoing process is maintained to develop teachers' quality as well as improve their prosperity.

\section{CONCLUSSION}

As one of the way or policy in improving the quality of the teachers, teacher certification program need to be followed up by several ongoing activities such monitoring and evaluation, these activities are intended to monitor the sustainable professional development done by the teachers. Continued selfimprovement and reflection by the teachers are also required to maintain and build the teachers' creativity and innovation on their profession such teaching skills as well as they upgrade and update their instructional materials. Therefore, teacher certification program is not only one episode of teacher training measurement but it will be more on lifelong assessment for teachers' quality improvement. 


\section{REFERENCES}

Brown, H.D. 2007. Teaching by Principles. An Interractive Approach to Language Pedagogy. (Third Edition). White Plains, NY: Pearson Education.

Departemen Pendidikan Nasional. 2003. Undang-Undang Republik Indonesia Nomor 20 Tahun 2003 Tentang Sistem Pendidikan Nasional. Jakarta: Biro Hukum dan Organisasi Sekretariat Jenderal Departemen Pendidikan Nasional.

Departemen Pendidikan Nasional. 2006. Materi Sosialisasi Program Sertifikasi.

Departemen Pendidikan Nasional. 2007. Undang - Undang no 16 tahun 2007 tentang Standar Kualifikasi Akademik dan Kompetensi Guru. Jakarta: Depdiknas.

Halim, T. 2011. Teacher Certification in Indonesia. International Conference on Social Science, Economics and Art. Putrajaya, Malaysia.

Khodijah, N. 2010. Kinerja Guru Pasca Sertifikasi (Studi Terhadap Kinerja Guru Madrasah dan Guru Pais Pada Sekolah Umum di Propinsi Sumatera Selatan). Scientific Article.

Samani Muchlas dkk. 2006. Mengenal Sertifikasi Guru di indonesia. Surabaya: SIC dan Asosiasi Peneliti Pendidikan Indonesia (APPI).

Setiawan, R. 2009. The Effectiveness of Teacher Training in Indonesia: A practice by Sampoerna Foundation Teacher Institute (SFTI). Published jounal. http://creativecommons.org/licenses/by-nc-nd/2.0/de/.

Triyanto, 2012. Improving Teacher Profesionalism through Certification Program: An Indonesia Case Study. Published Journal. World Academy of Science, Engineering and Technology.

Undang-Undang Republik Indonesia No. 14 tahun 2005 tentang Guru dan Dosen.

Winarsih. 2008. Implementasidr Kebijakan Sertifikasi Guru Sekolah Dasar (Studi Kasus Di Kabupaten Semarang). Semarang:Universitas Diponegoro. 